\title{
A Study on Women Empowerment through Self- Help Groups with Special Reference to Mettupalayam Taluk In Coimbatore District
}

\author{
S.Thangamani ${ }^{1}$, S.Muthuselvi ${ }^{2}$ \\ ${ }^{1}$ (Dept of Commerce(CA),Dr.SNS.Rajalakshmi College Of Arts and Science, INDIA) \\ 2 (Dept of Commerce(CA),Dr.SNS.Rajalakshmi College Of Arts and Science,INDIA)
}

\begin{abstract}
Women empowerment is a process in which women challenge the existing norms and culture, to effectively promote their well being. The participation of women in Self Help Groups (SHGs) made a significant impact on their empowerment both in social and economical aspects This study addresses women empowerment through self help groups in Mettupalayam district of Tamilnadu. The information required for the study has been collected from both the primary and secondary sources A Random sampling method has been followed. Average and percentage analysis was carried out to draw meaningful interpretation of the results. Chi - Square test used to find whether the two attributes are associated or not. Garret ranking technique was used to find the reasons for joining the Self help group. The results of the study revealed that the SHGs have had greater impact on both economic and social aspects of the beneficiaries.
\end{abstract}

Key words: Woman Empowerment, SHG, Mettupalayam, Tamilnadu.

\section{Introduction}

The concept of Self Help Groups serves to underline the principle "for the people, by the people and of the people". The Self Help Groups is the brain child of Gamelan Bank of Bangladesh, which was founded by Prof. Mohammed Yunas of Chittagong University in the year 1975. The Self Help Groups scheme was introduced in Tamilnadu in 1989. The activism within the women movement has influenced the government to frame policies and plan for the betterment of the country. The empowerment of women through Self Help Groups (SHGs) would lead to benefits not only to the individual women, but also for the family and community as a whole through collective action for development. Self Help Groups have linkages with NGOs (NonGovernment Organizations) and banks to get finance for development. In turn it will promote the economy of the country by its contribution to rural economy. Self Help Groups are small voluntary associations of rural people, preferably women folk from the same socio-economic background. They come together for the purpose of solving the common problems through self-help and mutual help in the Self Help Groups.

\section{Review Of Literature}

During the course of the study, the study of several authors was referred and it is imperative that an outline of the literature survey is put to note and the following references are worth mentioning. According to Agarwal, Deepti (2001),"Women need to be viewed not as beneficiaries but as active participants in the progress of development and change empowerment of women could be organized into groups for community participation as well as for assertion of their rights in various, services related to their economic and social well being".

Manimekalai and Rajeswari (2002), conducted a study on "Grass roots entrepreneurship through Self Help Groups (SHGs)", with the objective to find out the factors which have motivated women to become Self Help Group members are eventually entrepreneurs and analyze the enterprise performance of Self Help Groups in terms of growth of investment, turnover, capacity utilization, profit etc.It is understand from the analysis that the Self Help Group entrepreneurs have improved a lot with respect to their enterprise performance. It is observed that the women have been depending only on agriculture and now have become independent. Apart from the improvement on the personal growth, the community as a whole has gained through the organization of the Self Help Groups.

Jaya S.Anand (2002), in her discussion paper titled "Self Help Groups in empowering women; case study of selected Self Help Groups and Neighbor Hood Groups(NHGs)", gives a review of progress of Self Help Groups. She has attempted to examine the performance of selected Self Help Groups and NHGs and to assess its impact, especially the impact of micro credit programme on empowering women. It has been clearly established that delivering credit alone may not produce the desired impact. The supporting services and structures through which credit is delivered remaining from group formation and training to awareness raising and a wide range of other supporting measures are critical to make the impact of group activity strong and sustainable. 
Vasudeva Rao (2003) conducted a study on "Self Help Groups and Social change" with the objective to study the improved status and quality of life of poor women and children in the rural areas and the involvement of community in planning .To achieve the objectives of the study a sample of 1.5 percent, out of 2.19 lakh self help group in Andra Pradesh, was taken. It is observed that the self interest and self motivation would go a long way for the sustenance of the group. The share of women in decision making regarding important domestic matter is varying between districts and caste groups. The rate of illiteracy can be further reduced through the existing programmes.

Mahendra Varman.P(2005),in a paper title, "Impact of Self Help Groups on formal banking Habits", makes a model attempt to examine whether there is any association between the growth of Self Help Groups and the increase in female bank deposit accounts and whether Self Help Groups have a tendency to influence account holding in formal banks among individual households. The analysis also reveals that being member in Self Help Groups and more importantly having leadership experience in Self Help Groups greatly influence the bank account holding. Leadership experience in Self Help Groups would also improve an individual banking habits.

Dr.S.Rajamohan in this study "opinion of the members of self help groups(2005) reveals that Self Help Group helps them to increase their status and aids to raise the standard of living of them. Women are becoming entrepreneurs with the help of Self Help Groups which avoids the exploitation of women and helps empowering them.

Mr.B.vijayachandra pillai, V.Harikumar (2006),In their research "SHGs is highly relevant to make the people of below poverty line " says the very existence of SHGs is highly relevant to make the people of below poverty line hopeful and self reliant. SHGs enable to increase their income improve their standard of living and status in society to the main stream ultimately, the nation reaps the advantages of socialism.

\section{Statement Of The Problem}

During the planning area several efforts were made by the Government of India to increase the role of women and to improve the status of women. Self-Help Groups (SHGs) are increasingly becoming very important method of organizing women to take action and transform their situation. The strength of Self Help Groups is based upon the fact that the people who are facing problems are likely to be the most committed to solve them. The inability of formal credit institutions to cover rural poor is generally attributed to high cost of administering the large number of small loans. This has promoted large number of Non Government Organisations (NGOs) to enter the rural credit scheme for organizing the poor into informal groups. For mutual help, these groups are instrumental in promoting informal structure of the poor to help them save and promote self reliance in financing these needs through Self Help Groups. But still poor have financial crisis. Their poverty still persists. In this context study is proposed to carry out further stuffy in micro financing.

Self Help Groups have emerged as one of the major strategies for the convergence of services and activities different Self Help Groups in different states of the country have focused on: Skill development, Awareness generation, Gaining access to credit from financial institutional for micro enterprise projects and inculcation of thrift and management of credit for the economically deprived sections of women and so on.

Hence, it is of considerable interest to study the role of Self-Help Groups in the socio-economic status of women in Tamilnadu. But considering the empowerment of Self Help Group members, this study is undertaken to find out the answer to following questions.

1. What are the socio economic characteristics of the respondents?

2. What are the reasons to joining Self Help Group?

3. What are the factors determining Self Help Group?

4. What are the levels of satisfaction regarding Self Help Groups?

5. What are the problems faced by the members in Self Help Groups?

\section{Objectives Of The Study}

The objectives of the present study are proposed the following objectives.

1. To study the socio-economic background of the women beneficiaries and their family characteristics.

2. To analyses the income, expenditure and savings pattern of the Self Help Groups members.

3. To study the level of satisfaction of members in Self Help Group.

4. To find out the benefits through Self Help Group.

5. To find out the problems faced by the members in Self Help Groups.

6. To explore future strategies and to suggest measures for the better management of Self Help Groups.

\section{Research Methodology:}

The study used primary data and secondary data for analysis according to the objective set out in the study.Primary data were collected by interview schedule method. Secondary data were collected from websites 
and subject books. Simple frequency tables and charts were constructed for the purposes of analysis of data. Convenient sampling method is used to select the respondents. The present study has covered from Mettupalayam Taluk from Coimbatore District, Tamil Nadu. It was selected for this study, because of the Self Help Groups members are functioning very successful manner and also researchers own district. Therefore Mettupalayam taluk was selected for the present study. The sample size is two hundred respondents constituting all categories of Self Help Group members from Mettupalayam Taluk.

\section{Orgin Of The Study}

The origin of Self Help Groups (SHGs) is the brainchild of Grameen Bank of Bangaladesh, founded by Prof. Mohammed Yunus in 1975, who tried out a new approach to rural credit in Bangaladesh. Grameen gave loans without asking borrowers either to provide collateral or engage in paper work. In India NABARD initiated SHGs in the year 1986-87 But the real effort was taken after 1991-92 from the linkage of SHGs with the banks. A SHG is a small economically homogeneous affinity group of the rural poor voluntarily coming forward to save a small amount of money regularly, which is deposited in a common fund to meet the members ${ }^{\text {ee }}$ emergency needs and to provide collateral free loans decided by the group. The SHGs have been recognised as useful tool to help the poor and as an alternative mechanism to meet the urgent credit needs of poor through thrift( N. Thalavai pillai and S. Nadarajan 2010).

\section{Working Pattern Of Self-Help Groups}

$>\quad$ Self Help Group collects deposit from their members and length to needy member for production purpose and for subsistence and consumption needs.

Self Help Group also takes loans from banks to meet the needs of their members.

Non-Government Organization helps the Self Help Group in processing raw materials and marketing the produce.

$>$ Entire loan amount disbursed to Self Help Group is refinanced by National Agricultural Bank for Rural Development to the financing bank.

\section{Analysis And Interpretation}

SHG members in their socio-economic conditions and other related factor through the structured interview schedule collected by the researcher. For this purpose the study conducted for two hundred respondents of the SHG members were selected from various Self Help Group's in Mettupalayam Taluk, Coimbatore District. In this part, the result of Chi - Square test, Garret ranking and Opinion survey are presented.

\subsection{SIMPLE PERCENTAGE ANALYSIS}

Percentage analysis was carried out and interpretation done keeping in mind the objective of the study.

\subsection{CHI - SQUARE TEST}

Chi - Square test used to find whether the two attributes are associated or not. In other words this test is used to find one variable has a significant influence in the other. In this study the Chi - Square test is used between personal factor and study related factors.

Chi - Square test is applied using the formula:

$$
\mathrm{X}^{2}=\mathrm{E}(\mathrm{Fo}-\mathrm{Fe})^{2} / \mathrm{Fe}
$$

Where:

$$
\begin{aligned}
& \mathrm{Fo}=\text { Observed Value } \\
& \mathrm{Fe}=\text { Expected Value }
\end{aligned}
$$

Degree of freedom $=(\mathrm{C}-1) *(\mathrm{R}-1)$

Where:

$\mathrm{R}=$ Number of rows

$\mathrm{C}=$ Number of columns

The calculated value of $\mathrm{Chi}$ - Square is compared with the table value at $5 \%$ level of significance and inferences drawn.

\subsection{GARRET RANKING}

This technique was used to rank the preference of the respondents on different aspects of the study. The orders of merit given by the respondents were converted into ranks by using the following formula.

Percentage Position $=$

$$
100\left(\mathrm{R}_{\mathrm{ij}}-0.5\right)
$$

$$
\mathrm{N}_{\mathrm{j}}
$$

The percentage position of each rank thus obtained into scores by referring to the table given by Henry E.Garret. Then for each factors the scores of individual respondents are added together and divided by the 
total number of the respondents for whom the scores were added. These mean scores for all factors were arranged in the descending order, ranks given and most important aspects identified.

\subsection{OPINION SURVEY}

The respondent's opinion about their satisfaction is given in the table. Their opinions are classified as highly satisfied, satisfied, dissatisfied, highly satisfied and no opinion.

TABLE - 4.1.1

AGE OF THE SELF HELP GROUP MEMBERS

\begin{tabular}{|l|l|c|c|}
\hline S.No & Age & No. of Respondents & Percentage(\%) \\
\hline 1 & Below 30 Years & 56 & 28 \\
\hline 2 & $31-40$ Years & 75 & 37.5 \\
\hline 3 & Above 40 Years & 69 & 34.5 \\
\hline & Total & $\mathbf{2 0 0}$ & $\mathbf{1 0 0}$ \\
\hline
\end{tabular}

Source: Primary Data

Interpretation

From the above table reveals that out of total respondents taken for the study, $28 \%$ of them belong to the age group of 30 years, $37.5 \%$ of the respondents are 31 to 40 years, and remaining $34.5 \%$ of them belong to age group of above 40 years.

Inference

Majority of the respondents falls under the age group of 31 to 40 years.

TABLE 4.1.2

EDUCATIONAL STATUS OF THE SELF HELP GROUP MEMBERS

\begin{tabular}{|l|c|c|c|}
\hline S.no & $\begin{array}{l}\text { Educational } \\
\text { Qualification }\end{array}$ & $\begin{array}{l}\text { No. } \\
\text { Respondents }\end{array}$ & $\begin{array}{c}\text { Percentage } \\
(\mathbf{\%})\end{array}$ \\
\hline 1 & Illiterate & 48 & 24 \\
\hline 2 & Literate & 152 & 76 \\
\hline & Total & $\mathbf{2 0 0}$ & $\mathbf{1 0 0}$ \\
\hline
\end{tabular}

Source: Primary Data

Interpretation

Table 4.1.2 shows that educational status of the Self Help Group members, $76 \%$ of the members are literate and remaining $24 \%$ of the members are illiterates.

Inference

In this study, the maximum respondents are literate 76 Percent among 100 Percent.

TABLE - 4.1.3

FAMILY STATUS OF THE SELF HELP GROUP MEMBERS

\begin{tabular}{|c|c|c|c|}
\hline S. No & Marital Status & No. of Respondents & $\begin{array}{c}\text { Percentage } \\
(\mathbf{\%})\end{array}$ \\
\hline 1 & Joint & 65 & 32.5 \\
\hline 2 & Nuclear & 135 & 67.5 \\
\hline & Total & $\mathbf{2 0 0}$ & $\mathbf{1 0 0}$ \\
\hline
\end{tabular}

Source: Primary Data

Interpretation

The above table reveals that out of the total respondents taken for the study, $32.5 \%$ of them are joint family and remaining $67.5 \%$ of the respondents are nuclear family.

Inference

Majority of the respondents are nuclear family.

TABLE- 4.1.4

KNOW ABOUT THE SELF HELP GROUP

\begin{tabular}{|c|c|c|c|}
\hline S.no & $\begin{array}{c}\text { Know About the Self Help } \\
\text { Group }\end{array}$ & No. of Respondents & $\begin{array}{c}\text { Percentage } \\
(\mathbf{\%})\end{array}$ \\
\hline 1 & $\begin{array}{c}\text { Non-Government } \\
\text { organizations }\end{array}$ & 98 & 49 \\
\hline 2 & Government & 33 & 16.5 \\
\hline 3 & Bankers & 40 & 20 \\
\hline 4 & Others & 29 & 14.5 \\
\hline & Total & $\mathbf{2 0 0}$ & $\mathbf{1 0 0}$ \\
\hline
\end{tabular}

www.iosrjournals.org 
Source: Primary Data

Interpretation

The table 4.1.4 shows that knowledge about to start in the self help groups from $49 \%$ of members opinion by the Non-Government Organization. The another important role for

TABLE- 4.1.5

REASON FOR JOINING OF SELF HELP GROUP MEMBERS

\begin{tabular}{|l|l|l|l|}
\hline S.No & Statement & No. of Respondents & Percentage (\%) \\
\hline 1 & $\begin{array}{l}\text { To attain the economic } \\
\text { independence }\end{array}$ & 42 & 21 \\
\hline 2 & For passing time & 12 & 6 \\
\hline 3 & To get recognition from the society & 30 & 15 \\
\hline 4 & For Savings & 78 & 39 \\
\hline 5 & To show the talents & 22 & 11 \\
\hline 6 & Other & 16 & 8 \\
\hline & Total & $\mathbf{2 0 0}$ & $\mathbf{1 0 0}$ \\
\hline
\end{tabular}

Source: Primary Data

Interpretation

The opinion for joining the self help group as a members, the table 4.1 .5 shows that $39 \%$ of the respondents opinion regarding for enriching the saving, the second importance for to attain the economic independence (21\%), and remaining to recognition from the society, show the talents, and others. Only $6 \%$ of the members opinion reveals that for passing time.

Inference

Most of the respondents are joining for saving purpose.

HYPOTHESIS

The following null hypothesis were framed and significant of these were tested with chi-square test with 5 per cent level of significance.

$\mathrm{H}_{\mathrm{o}}$ : There is no significant relationship between education qualification and membership period in self help groups

$\mathrm{H}_{1}$ : There is significant relationship between education qualification and membership period in self help groups

TABLE -4.1.6

EDUCATION QUALIFICATION AND MBERSHIP PERIOD IN SELF HELP ROUPS

\begin{tabular}{|c|c|c|c|c|}
\hline Factors & $\begin{array}{c}\text { Calculated } \\
\text { Value }\end{array}$ & Table Value & $\begin{array}{c}\text { Degree of } \\
\text { Freedom }\end{array}$ & $\begin{array}{c}\text { Result } \\
\text { of 5\% } \\
\text { Level }\end{array}$ \\
\hline $\begin{array}{c}\text { Age and membership } \\
\text { period in self help } \\
\text { groups }\end{array}$ & 5.45 & 9.49 & 4 & Not Significant \\
\hline $\begin{array}{c}\text { Education qualification } \\
\text { and membership period } \\
\text { in self help groups }\end{array}$ & 1.40 & 5.99 & 2 & Not Significant \\
\hline $\begin{array}{c}\text { Marital status and } \\
\text { membership period in } \\
\text { self help groups }\end{array}$ & 10.56 & 5.99 & 2 & Significant \\
\hline $\begin{array}{c}\text { Member occupation and } \\
\text { membership period in } \\
\text { self help groups }\end{array}$ & 1.22 & 12.6 & 6 & Not Significant \\
\hline $\begin{array}{c}\text { Monthly income and } \\
\text { member's self-help group } \\
\text { occupation }\end{array}$ & 2.57 & 12.6 & 6 & 6 \\
\hline $\begin{array}{c}\text { Earning member in the } \\
\text { family and family } \\
\text { benefits }\end{array}$ & 2.05 & 9.49 & & Not Significant \\
\hline
\end{tabular}


Hence it may be concluded that the statistical analysis that the test proved Not significant and hence the null hypothesis should be accepted at 5\% level, that there are no significant relationship between age, education, occupation, monthly income and earnings in self help groups. The null hypothesis should be accepted at $5 \%$ level, there is significant relationship between marital status and membership period in self-help groups.

\section{GARRET SCORE}

TABLE - 4.1 .7

Table-4.3.2 shows the Garret Scores. Firstly the Garret ranks are calculated by using appropriate Garret ranking formula. Then based on Garret ranks the table value is ascertained. Garret table an scoresof each advantage in Table-4.3.2 are multiplied to find out scores in the table which are then multiplied to record scores in Table-4.3.2.Finally by adding each row, we get total score.

\begin{tabular}{|c|c|c|c|c|c|c|c|c|}
\hline \multirow{2}{*}{ S.no } & \multirow{2}{*}{ Factors } & \multicolumn{6}{|c|}{ Rank } & \multirow{2}{*}{$\begin{array}{c}\text { Garret } \\
\text { 's } \\
\text { Score }\end{array}$} \\
\hline & & 1 & 2 & 3 & 4 & 5 & 6 & \\
\hline 1 & $\begin{array}{c}\text { Self - } \\
\text { employment }\end{array}$ & 5236 & 2268 & 2808 & 1104 & - & 460 & 11876 \\
\hline 2 & $\begin{array}{c}\text { Earning } \\
\text { money }\end{array}$ & 5236 & 3528 & 648 & 552 & 1440 & 276 & 11680 \\
\hline 3 & $\begin{array}{l}\text { Improving } \\
\text { social status }\end{array}$ & 924 & 1512 & 1944 & 1656 & 1872 & 920 & 8828 \\
\hline 4 & Sharing risk & 1540 & 756 & 1728 & 1840 & 1728 & 1104 & 8696 \\
\hline 5 & $\begin{array}{l}\text { Educating } \\
\text { children }\end{array}$ & 1232 & 3024 & 2592 & 1840 & 864 & 552 & 10104 \\
\hline 6 & $\begin{array}{l}\text { Serving the } \\
\text { society }\end{array}$ & 1232 & 1512 & 1080 & 2208 & 1296 & 1288 & 8616 \\
\hline
\end{tabular}

\section{GARRET RANKING}

TABLE - 4.1 .8

\begin{tabular}{|l|l|l|l|l|}
\hline S.no & Factors & $\begin{array}{l}\text { Garret's } \\
\text { Score }\end{array}$ & $\begin{array}{l}\text { Garret's } \\
\text { Rank }\end{array}$ & Average score \\
\hline 1 & Self - employment & 11876 & I & 118.76 \\
\hline 2 & Earning money & 11680 & II & 116.80 \\
\hline 3 & Educating children & 10104 & III & 101.04 \\
\hline 4 & Improving social status & 8828 & IV & 88.28 \\
\hline 5 & Sharing risk & 8696 & V & 86.96 \\
\hline 6 & Serving the society & 8616 & VI & 86.16 \\
\hline
\end{tabular}

The above table furnishes the Garret's Scores .The highest score is awarded to self - employment .The least score is awarded to serving the society.

It is inferred that "Self- Employment" is the important factor of self help group.

\subsection{Findings Of Percentage Analysis}

\section{Findings}

1. Majority of 37.5 Percent of the respondents of the Self Help Group members are belonging to age group of 31 to 40 years.

2. Majority 76 Percent of the members are literate in self help groups.

3. Majority 67.5 Percent of the respondents are nuclear family.

4. Majority 79 Percent of the respondents are married

5. Majority 29 percent of the respondents fall under category of house wife in the occupation status.

6. Majority 42 Percent of the Self Help Group members family earning members are two.

7. Majority 62 Percent of the Self Help Group respondents family members between 3 to 5 .

8. Majority 45 Percent of the respondents monthly income are below Rs. 5000.

9. Self Help Group from 49 Percent of members opinion by the Non Government Organizations.

10. Majority 39 Percent of the respondents opinion regarding for enriching the saving for joining self help group.

11. Majority 46 Percent of the respondents have membership period above 4 years.

12. Majority 47 Percent of the respondents are attend the meeting weekly once.

13. Majority 34 Percent of the Self help group members Self Help Group linked with the State bank of India.

14. Majority 46 Percent of the respondents are invested in their venture for below Rs. 10000. 
15. Majority 31 percent are started small petty shop through self help group.

16. Majority 80 Percent of the respondents are motivating others to join Self Help Group.

17. The opinion of the formation process 82 Percent of the members reveals that make easy.

18. Majority 52 Percent of the respondents are attend the training programme.

19. Majority 88 Percent of the respondents are satisfied with economically improved their family.

20. Majority 48 Percent of the respondents have positive changes in self confidence.

\subsection{Findings Of Chi Square Test}

1. There is no significant relationship between age and membership period.

2. There is no significant relationship between educational qualification and membership period.

3. There is significant relationship between marital status and membership period.

4. There is no significant relationship between members occupation and membership period.

5. There is no significant relationship between members occupation and initial investment amount.

6. There is no significant relationship between monthly income and SHG members occupation.

7. There is no significant relationship between earning members and family benefits.

\section{3findings Of Garret Ranking}

D The highest score is awarded to self - employment .The least score is awarded to serving the society.

$>\quad$ It is inferred that "Communal Misunderstanding" is the important factor of self help groups.

\subsection{FINDINGS OF OPINION SURVEY}

$>$ Over all opinion of the respondents are highly satisfied.

\section{Suggestions}

1. The self help groups and its importance must be implementing as lesson of text book among school; level education.

2. Self Help Group is powerful tool to enrich the savings activities and poverty alleviation. In this context to support by the government and uplift the women through Self Help Group oriented developments.

3. More schemes can be introduced by the government and it has not be communicated and advertised proper way to reach the Self Help Groups. So the Non Government Oganisations and other support agencies to deals with Self Help Group with periodical intervals. In the aspects, Self Help Group members more satisfied and benefited.

4. In order to strength the women empowerment, female literacy has to be promoted

5. Rotation of responsibility has to be made compulsory, so that it will lead to women's empowerment.

6. None of the voluntary agencies was found to be making efforts to develop a second line leadership to take up the leadership role. It was observed that a few women were dominating the show from year to year. A trend seemed to have emerged paving the way for the educated and the "better off leader dominating the groups and getting reelected again and again.

7. The group leader educates the entire team to manage the groups and maintain accounts and other record of the groups. It may lead to lopsided empowerment and not empowerment in the full sense.

8. It is suggested that the Non Government Organizations should be prevented from interfering with Self Help Groups movement. Steps should be taken to keep them as voluntary organizations and they should not be allowed to use extraneous influences

9. Since majority of the women are ignorant of their legal rights, legal literacy classes should be organized to enhance their awareness.

10. In many of the Self Help Groups, the same person is continuing in the offices as group secretary. So, rotation of the group's secretary is necessary for equitable exposure to the banking transaction.

\section{Conclusion}

The study was undertaken to identify women empowerment through Self Help Group in Mettupalayam Taluk. It is found that the socio- economic factor has been changed after joining the Self Help Groups. But the saving is increasing at earlier stage of life. There are emerging issues that need to be addressed to make the role of women in the long run. It is the clear that by involving voluntary organizations in social mobilization and creating an enabling policy environment, micro fiancé can achieve a vast scale and can become a rational movement. The self help group is important in re-strengthening and bringing together of the human race. We may conclude that the economic activities of Self Help Group are quite successful. In this way Self Help Group in Mettupalayam Taluk the very successful develop women empowerment and rural areas. 
BOOKS:

\section{References}

[1]. Dr.S.P.Gupta, StatiscalMethods, Sultan hand and Sons Educational Publisher, New Delhi-2006.

[2]. C.R.Kothari,Research,methodology method and techniques, New Age International (P) Ltd, Publishing New Delhi ,Ed-2004.

[3]. Philip Kolter, Marketing Management, The Millanium Edition, Prentice Hall of India Private Limited, New Delhi, Ed-2000.

WEBSITE:

[4]. www.google.com

[5]. Www.wikipedia.com

\section{JOURNALS}

[6]. Indian journal of social welfare

[7]. Kurkshetra

[8]. Economic and political weekly magazine. 